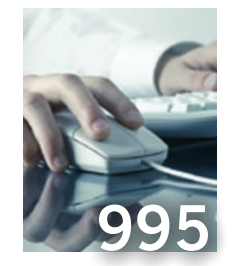

Web reactions:

A patient-based

approach tracks

drug response

\title{
Revamped guidelines aim to keep pace with stem cell advances
}

This time last year, three scientific papers were nearing the end of their rigorous peerreview process at several of the world's best known scientific journals, to be published in November. Dozens of the most respected biologists had reviewed them, and editors at the journals had spent fitful nights wondering if they had missed any small detail.

Simply put, those papers revealed that mere human skin cells could be transmuted into the near-perfect likeness of embryonic stem cells (Cell 131, 861-872; 2007; Science 318, 1917-1920; 2007; Nat. Biotechnol., doi:10.1038/nbt1374;2007). Only the debunked achievements of the scientist Woo-Suk Hwang had ever loomed as big in the consciousness of the stem cell community.

Now, less than a year later, the science building on these induced pluripotent stem cells' (iPS cells) derived from adult tissue is rushing forward at breakneck speed-and the agencies that have taken on the responsibility of regulating this research are trying their best to keep up.

Experts must reach a consensus before issuing guidelines, and thus drafting such documents can involve an arduous process. Nonetheless, on 5 September, the US National Academies, which include the National Academy of Sciences and the Institute of Medicine, released an amended set of stem cell research guidelines that included an entirely new section for iPS cells. The International Society for Stem Cell Research (ISSCR), meanwhile, has issued a draft version of recommendations on how to move iPS cellbased technology into clinical trials.

"The stakes are big, and missteps are extremely costly," says Alta Charo, a professor of bioethics at the University of Wisconsin and co-chair of the National Academies' Human Embryonic Stem Cell Research Advisory Committee. "Anything with the tag 'stem cell' is going to be controversial, and we've already had a couple of unfortunate incidents that have given people reason to be skeptical."

Just last month, The Lancet retracted a June 2007 study from an Austrian team that had apparently found a successful stem cell treatment for urinary incontinence (Lancet 369, 2179-2186; 2007). An investigation has reportedly found evidence that the team failed to receive proper ethics approvals for the research and to fully inform the study participants about the known risk of the experimental treatment.

"These issues occur in every field of research, but when they happen in stem cell science they get so much attention that they do real damage in terms of the support from the public that is absolutely fundamental to keep this research going," says Geoff Lomax, the senior officer for medical and ethical standards at the California Institute for Regenerative Medicine (CIRM).

The best protection is for well updated guidelines to be in place and for agencies to follow them, he said. This is especially true for iPS cells.

\section{A mix of concern}

The new guidelines for iPS cell technology issued by the National Academies state that such research need be held only to individual institutional review board standards. However, it stresses that the ethical implications of iPS technology are as important as work done with human embryos, especially when dealing with potential creation of chimeras in which human tissue is combined with animal tissue.

The new guidelines from the ISSCR will probably focus on similar ethical concerns relating to the use of iPS cells in human clinical trials. No such experiments have been proposed thus far, but researchers like Lomax predict that a lack of specific guidance might lead to incidents similar to the recent Austrian debacle.

Although recommendations from the National Academies and ISSCR have been widely lauded in the research community, many institutions and countries have recently established their own set of guidelines and governance, and the proliferation of multiple standards is a cause of concern among some researchers.

"Back when the [National Academies]

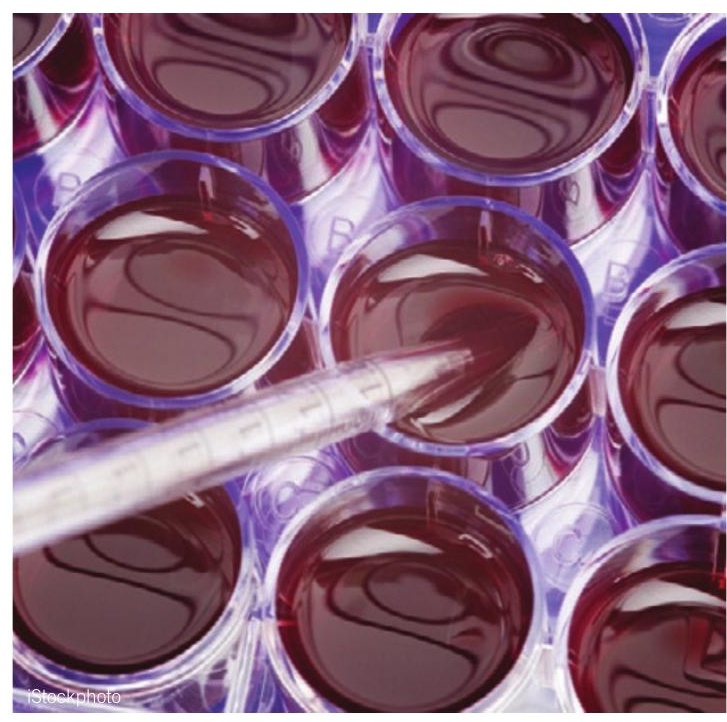

Potential for abuse: Rules outline best practice

issued their stem cell policy guidelines in 2005, they set the standard," says Kevin Eggan of the Harvard Stem Cell Institute in Cambridge, Massachusetts. "But that's just not the case anymore, and that's bound to bring up some clashes in thought."

For example, Eggan and many other researchers disagree with the National Academies' 'wallet no lighter' policy, which states that women donating eggs for stem cell therapies can only be reimbursed for expenses and lost work. The policy's detractors say that this compensation scheme effectively makes wealthy women's eggs more valuable than those of poor women.

However, no matter what the ethical debate, changing the policy would be practically impossible, because any stem cell lines derived from 'bought' eggs wouldn't be available for use by researchers in the UK or researchers funded by the CIRM, Charo says.

"We're all trying to find the best way to proceed with what could be one of the most significant realms of research in modern medical history," she says. "And so far, I think we're doing pretty good."

Stu Hutson, Gainesville, Florida 